\title{
VALORIZATION OF CARBON NANOTUBE MATERIAL OBTAINED FROM POLYETHYLENE WASTE AS AN ADSORBENT FOR DYES FROM WASTEWATER
}

\author{
Gordana Bogoeva-Gaceva $^{1,3, *}$, Metodija Najdoski ${ }^{2,3}$, Viktor Stefov $^{2,3}$, Suat Ibishi ${ }^{2,4}$ \\ ${ }^{1}$ Faculty of Technology and Metallurgy, Ss. Cyril and Methodius University, Skopje, Macedonia \\ ${ }^{2}$ Faculty of Natural Sciences and Mathematics, Ss. Cyril and Methodius University, Skopje, Macedonia \\ ${ }^{3}$ Research Center for Environment and Materials, MANU, Skopje, Macedonia \\ ${ }^{4}$ State University of Tetovo, Tetovo, Macedonia \\ *gordana@tmf.ukim.edu.mk
}

\begin{abstract}
The objective of this investigation was to determine the efficiency of carbonaceous material, consisting of MWCNTs and amorphous carbon obtained by waste polyethylene pyrolysis, as an adsorbent for reactive textile dyes. In this work, the preliminary results of adsorption process of Bezaktiv Blau V-3R reactive dye from a solution with an initial $30 \mathrm{mg} / \mathrm{l}$ concentration using low dosage of adsorbent are presented. The results show that this material has promising potential as a sorbent, and its adsorption capacity $(140 \mathrm{mg} / \mathrm{g}$ ) for a reactive (anionic) dye is similar to some commercial MWCNT and functionalized MWCNT-based adsorbents.
\end{abstract}

Keywords: adsorption; anionic dyes; carbon nanotubes; amorphous carbon

\section{ВАЛОРИЗАЦИЈА НА МАТЕРИЈАЛ ОД ЈАГЛЕРОДНИ НАНОЦЕВКИ ДОБИЕН ОД ОТПАДЕН ПОЛИЕТИЛЕН КАКО АТСОРБЕНТ ЗА БОИ ОД ОТПАДНИ ВОДИ}

Целта на ова истражување беше да се испита ефикасноста на јаглероден материјал којшто содржи повеќеsидни јаглеродни наноцевки и аморфен јаглерод, добиен со пиролиза на отпаден полиетилен, како атсорбент за реактивни текстилни бои. Во трудот се презентирани прелиминарните резултати од процесот на атсорпција на реактивната боja Bezaktiv Blau V-3R од раствор со почетна концентрација од $30 \mathrm{mg} / \mathrm{l}$ со примена на мал масен удел на атсорбент. Резултатите покажаа дека јаглеродниот материјал ветува како можен атсорбент и неговиот атсорпционен капацитет $(140 \mathrm{mg} / \mathrm{g})$ за реактивната (анјонска) боја е сличен со оној на некои комерцијални повеќеsидни наноцевки и функционализирани атсорбенти на нивна основа.

Клучни зборови: атсорпција; анјонски бои; јаглеродни наноцевки; аморфен јаглерод

\section{INTRODUCTION}

Unlike the linear economy model (extractmanufacture-consume-throw away), the circular economy approach addresses material supply challenges by keeping materials in use much longer and eventually returning materials for new uses [1]. In general, the concept of circular economy is based on principles related to reusing, recycling, redesigning, repurposing, remanufacturing, refur- bishing, and recovering water, waste materials, and nutrients to preserve natural resources $[1,2]$.

The textile industry represents one of the world's most polluting industries, and it generates a huge amount of colored and toxic wastewaters [2]. Synthetic dyes (some of which are carcinogenic) used in huge amounts in the textile industry represent a specific group of pollutants posing a serious environmental threat. The wastewater from dyeing processes released into a natural aquatic 
system not only reduces light penetration but also negatively affects the photochemical activity of the aquatic system and might cause mutation in aquatic organisms. There are several techniques commonly used for the removal of organic dyes from wastewater. Among them, adsorption techniques have been considered as prevailing over other dye wastewater treatments due to their flexibility, simplicity of design and effectiveness [3].

In this paper, following the principles of circular economy, an attempt was made to purify dyeing wastewater by applying carbonaceous material obtained from waste plastic as an adsorbent for Bezaktiv Blau V-3R reactive dye. In our previous publication [4], we reported on the properties of carbonaceous material obtained by upcycling waste polyethylene via catalytic pyrolytic degradation. As revealed by thermal analysis, the obtained material contained multiwall carbon nanotubes (MWCNTs) with an average diameter of $80 \mathrm{~nm}$, and 20-30\% amorphous carbon [5].

\section{EXPERIMENTAL SECTION}

\subsection{Materials}

MWCNT material was obtained from lowdensity polyethylene waste by pyrolytic degradation using analytical grade cobalt(II) acetate dihydrate (Merck, Germany), as a catalyst in a simple one-stage procedure, as described in detail in our earlier publication [4]. Carbonaceous MWCNT material was employed in adsorption experiments without any further modification/treatment. Bezaktiv Blau V-3R (BB) reactive (anionic) dye was supplied by CHT/Bezema. Hydrochloric acid (analytical grade, Merck, Germany), was used for $\mathrm{pH}$ dye solution adjustment.

\subsection{Adsorption experiments}

The dye absorbance was measured at 570 nm wavelength, using a Cary 50 model Varian $\mathrm{UV}-\mathrm{V}$ is Spectrophotometer. The calibration curve of BB is shown in Figure 1. The solution of dye for adsorption experiments was prepared by diluting stock solution prepared from $1 \mathrm{~g}$ of dye powder in $1000 \mathrm{ml}$ deionized water in a volumetric flask, and then the solution was diluted to the desired initial dye concentration of $30 \mathrm{mg} \mathrm{l}^{-1}$. An amount of 10 $\mathrm{mg}$ of carbonaceous adsorbent material was added to a $100-\mathrm{ml}$ laboratory beaker with $50 \mathrm{ml}$ of dye solution (adjusted to $\mathrm{pH}=3$ ), and the beaker was placed on a magnetic stirrer with a stirring bar and stirred for $30 \mathrm{~min}$ at room temperature. The sam- ples of the solution were taken at predetermined time intervals to measure the dye concentration after contact with the adsorbent. The removal efficiency, $R(\%)$, was calculated from the final $\left(c_{\mathrm{f}}\right)$ and initial $\left(c_{0}\right)$ concentrations of the dye in solution:

$$
R=\frac{C_{o}-C_{f}}{C_{o}} \cdot 100
$$

The adsorption capacity (amount of dye adsorbed onto carbonaceous material, $A, \mathrm{mg} \mathrm{g}^{-1}$ ) was calculated by the mass balance relationship:

$$
A=\frac{C_{o}-C_{f}}{m} \cdot V
$$

where $c_{o}$ is the initial dye solution concentration in $\mathrm{mg} / \mathrm{l}, c_{f}$ is the final dye solution concentration in $\mathrm{mg} / \mathrm{l}, m$ is the mass of adsorbent in $\mathrm{g}$, and $V$ is the volume of dye solution in liters.

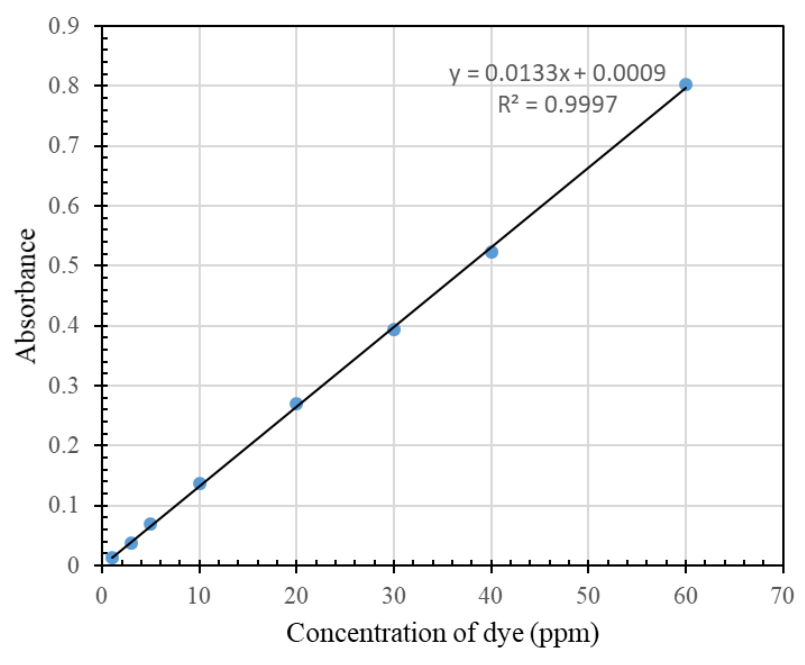

Fig. 1. Calibration curve of Bezaktiv Blau V-3R reactive dye

\section{RESULTS AND DISCUSSION}

Different organic and inorganic adsorbents are employed to remove organic pollutants found in textile effluents [6]. The application of carbon nanotube materials in dye wastewater treatment has recently received wide attention, because of their large surface area, hollow structure, and high aspect ratio [3, 6]. However, as far as we know, carbonaceous material consisting of both CNT and amorphous carbon has not been used for the adsorption of dyes so far.

Modification of CNTs is often performed to enhance their dispersibility in water since they are known as hydrophobic materials. The adsorption 
process depends primarily on the solid sorbent/dye molecule contact surface, and therefore the dispersion of the carbonaceous material is an important factor for dye removal efficiency. During the ad- sorption process, the dispersibility of the carbonaceous material under the applied experimental conditions was quite good, and the appearance of the solution after the treatment is shown in Figure 2.

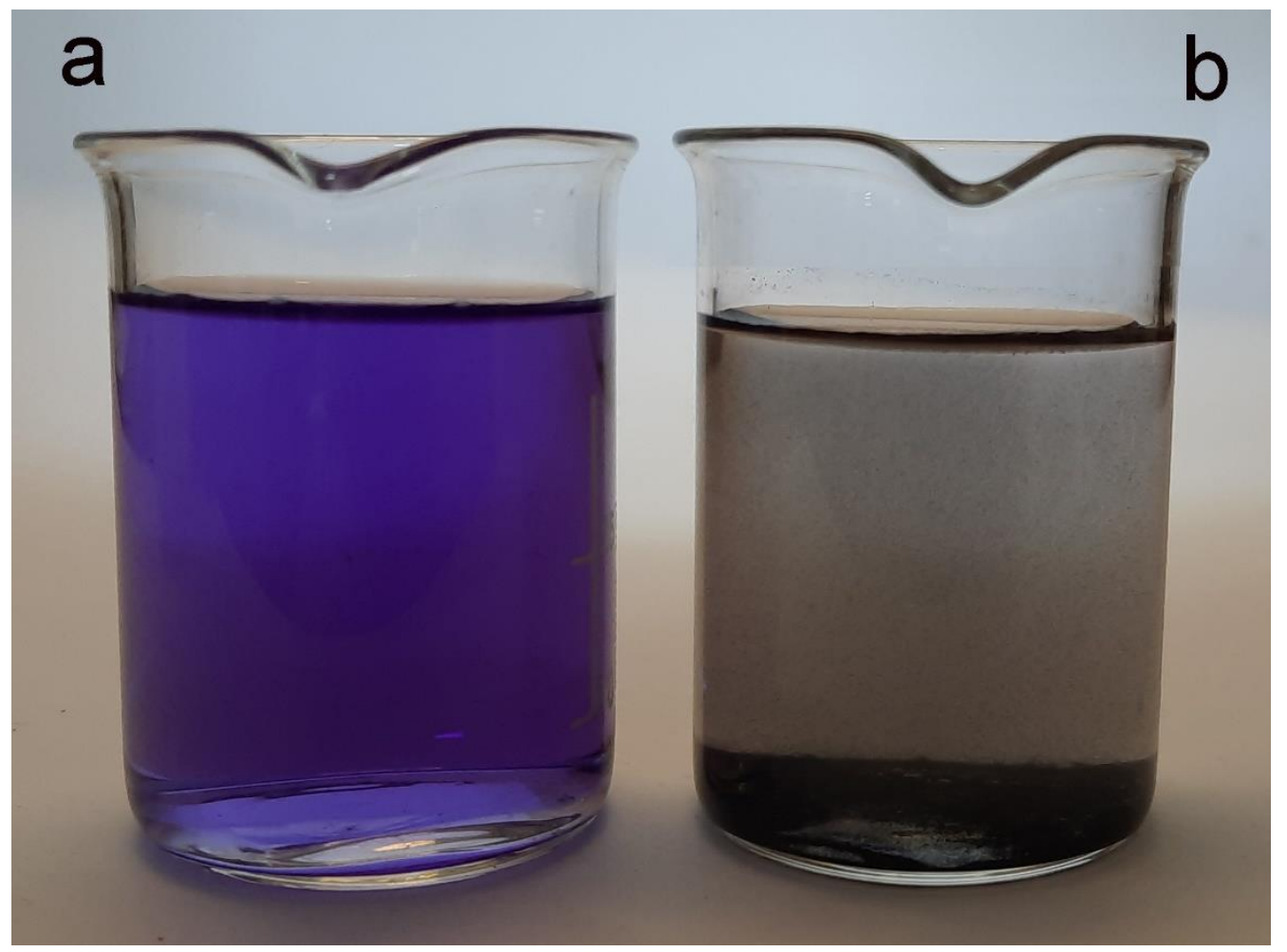

Fig. 2. Aqueous solution of dye with concentration $30 \mathrm{mg} / \mathrm{l}$, a) before adsorption treatment and $\mathbf{b})$ after the adsorption treatment

The $\mathrm{pH}$ of the solution is one of the main parameters in the adsorption of anionic and cationic dyes. In our experiments, the adsorption was carried out at a constant $\mathrm{pH}$ of 3 since a low $\mathrm{pH}$ value of the solution was found more suitable for the adsorption of anionic dyes [7]. The effect of contact time on the adsorption of BB dye is shown in Figure 3. The adsorption of dye was noticeably fast and it reached $80 \%$ after 5 minutes of contact with the adsorbent and almost $100 \%$ after 40-50 min. In the first $60 \mathrm{~s}$, adsorption was very fast (nearly $60 \%$ ), which may be attributable to the large number of free surface sites of MWCNTs and the sites of amorphous carbon that are available for sorption during the initial stage of contact with the dye molecules. The maximal adsorption capacity of the adsorbent under these experimental conditions was 140 mg/g (Fig. 4).

Low-cost adsorbents derived from solid and agricultural wastes have received widespread attention in recent decades. Chemically and thermally activated carbon obtained from palm tree fiber waste was recently applied for the removal of ani- onic and cationic dyes from wastewater [8]. A maximum adsorption capacity of $26.58 \mathrm{mg} \mathrm{g}^{-1}$ was determined for the cationic dye and a maximum adsorption capacity of $9.79 \mathrm{mg} \mathrm{g}^{-1}$ was determined for the anionic dye at an adsorbent dosage of 0.15 g. CNTs have been used as adsorbents for more than 15 years in the treatment of wastewaters from different industries. For several anionic dyes, adsorption capacities for CNTs of 27.6-152.0 $\mathrm{mg} \mathrm{g}^{-1}$ have been reported [9], and it was found that the dyes' molecular structure plays a more important role than the charge load for both azo dyes and CNTs.

Many factors are involved in dye adsorption processes regardless of the adsorbent used, such as the initial concentration of dye in wastewater, solution acidity, temperature, adsorbent dosage, and its physicochemical structure, as well as the type of dye-adsorbent interactions. Our further investigations will be focused on the influence of all important parameters on the removal efficiency of several anionic dyes using MWCNTs containing carbonaceous material. 


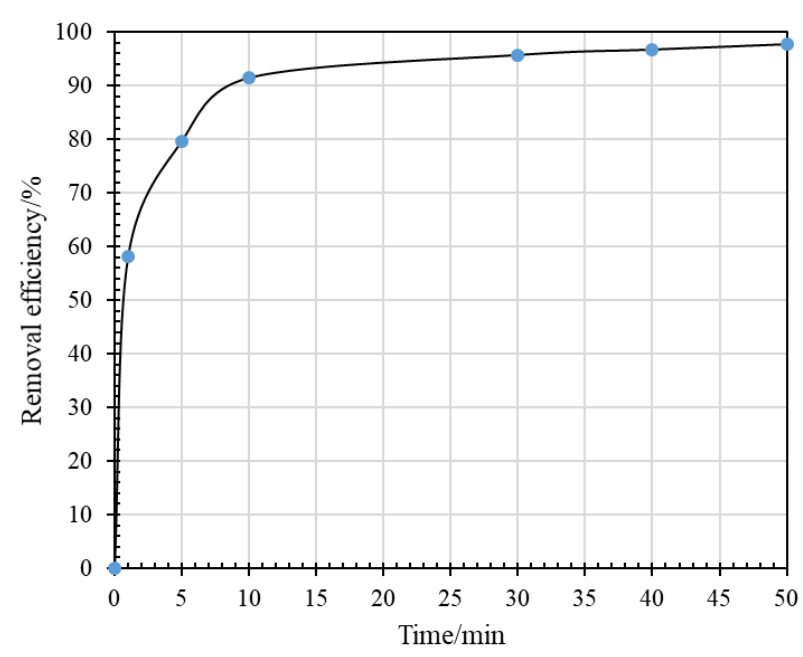

Fig, 3. The removal efficiency, $R$, of $\mathrm{BB}$ dye at $\mathrm{pH}=3$ versus contact time, $t$ (dye concentration $30 \mathrm{mg} / \mathrm{l}$ )

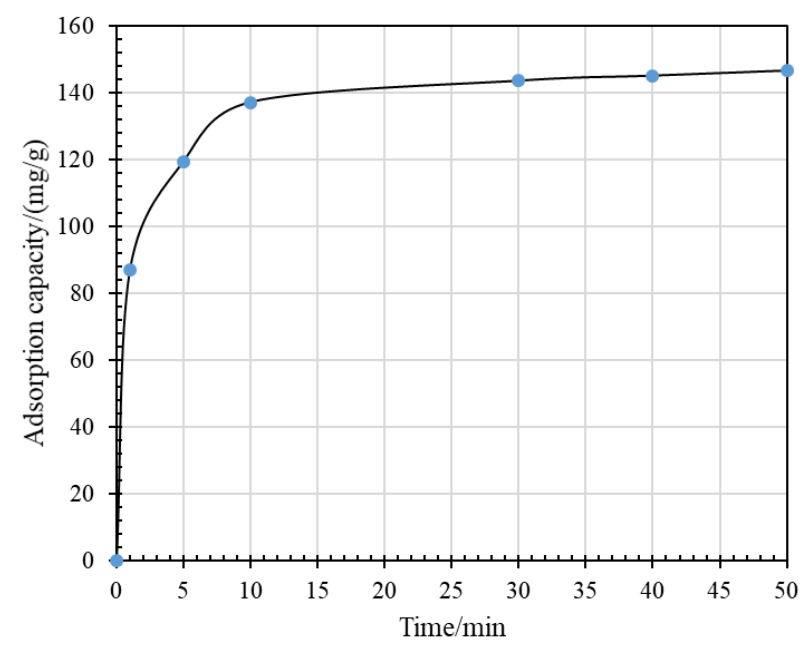

Fig. 4. Effect of contact time on BB dye adsorption capacity, $A(\mathrm{pH}=3$, dye concentration $30 \mathrm{mg} / \mathrm{l})$

\section{CONCLUSION}

In this paper, the adsorption potential of MWCNT carbonaceous material was assessed by evaluating its adsorption capacity for reactive (anionic) textile dyes. The results show that the material obtained by thermal upcycling of waste plastics represents a valuable carbonaceous adsorbent for ani- onic dye wastewater treatment, and it is a promising contribution on the way to a circular economy.

\section{REFERENCES}

[1] Circular Economy and Sustainability, Vol. 2: Environmental Engineering, Editors: A. Stefanakis and I. Nikolaou, ISBN: 9780128216644, eBook ISBN: 9780128232361 , Elsevier, 2021.

[2] N. R. Jessudos Hynes, J. Senthil Kumar, H. Kamyab, J. A. Jeniffa Sujana, O. A. Al-Khashman, Y. Kuslu, A. Ene, B. Suresh Kumar, Modern enabling techniques and adsorbents based dye removal with sustainability concerns in textile sector - A comprehensive review, $J$. Cleaner Prod. 272, 122636 (2020).

DOI: https://doi.org./10.1016/j.clepro.2020.122636

[3] G. N. Hlongwane, P. T. Sekoai, M. Meyyappan, K. Moothi, Simultaneous removal of pollutants from water using nanoparticles: A shift from single pollutant control to multiple pollutant control, Sci. Total Env. 656, 808-833 (2019). DOI: https://doi.org/10.1016/j.scitotenv2018.11257

[4] V. Stefov, M. Najdoski, G. Bogoeva-Gaceva, A. Buzarovska, Properties assessment of multiwalled carbon nanotubes: A comprehensive study, Synthetic Metals, 197, 159-167 (2014). DOI: https://doi.org/10.1016/j.synthmet.2014.09.011

[5] A. Bužarovska, V. Stefov, M. Najdoski, G. BogoevaGaceva, Thermal analysis of MWCNT material obtained by catalytic pyrolysis of polyethylene, Maced. J. Chem. Chem. Eng. 34, 373-379 (2015).

DOI: http://dx.doi.org/10.20450/mjcce.2015.620

[6] M. I. Mahammed, A. A. Abdul Razak, D. A. Hussein Al-Timimi, Modified multiwalled carbon nanotubes for treatment of some organic dyes in wastewater, $A d v . M a$ ter. Sci. Eng. Vol. 2014, Article ID 201052. DOI: http://dx.doi.org./10.1155/2014/201052

[7] M. Rajabi, K. Mahanpoor, O. Moradi, Removal of dye molecules from aqueous solution by carbon nanotubes and carbon nanotube functional groups: critical review, RSC Advances, 7, 47083-47090 (2017).

DOI: $10.1039 / \mathrm{c} 7 \mathrm{ra09377b}$

[8] B. G. Alhogbi, S. Altayeb, E. A. Bahaidarah, M. F. Zawrah, Removal of anionic and cationic dyes from wastewater using activated carbon from palm tree fiber waste, Processes, 9, 416 (2021). DOI: https://doi.org/10.3390/pr9030416

[9] K. B. Tan, M. Vakili, B. A. Horri, P. E. Poh, A. Z. Abdullah, B. Salamatinia, Adsorption of dyes by nanomaterials: Recent developments and adsorption mechanisms, Sep. Pur. Technol. 150, 229-242 (2015). DOI: http://dx.doi.org/10.1016/j.seppur.2015.07.009 